\title{
PERANCANGAN DAN IMPLEMENTASI APLIKASI PERPUSTAKAAN BERBASIS MULTITENANT
}

\author{
Khairul Fahmi $^{1)}$, Agus Tri Haryono ${ }^{2)}$, Indah Fitri Astuti ${ }^{3)}$, Dedy Cahyadi ${ }^{4)}$ \\ 1,3,4)Jurusan Ilmu Komputer, Fakultas MIPA, Universitas Mulawarman \\ Jalan Barong Tongkok No. 4 Kampus Gunung Kelua Samarinda, Kalimantan Timur \\ ${ }^{2)}$ ICT Universitas Mulawarman \\ Gedung UPT Distance Learning Kampus Gunung Kelua Samarinda 738327 \\ E-Mail : fahmik84@gmail.com ${ }^{1)}$, sandal.jepits@ gmail.com ${ }^{2)}$, indahfitriastuti@ yahoo.com ${ }^{3)}$, \\ dedy.cahyadi@gmail.com ${ }^{4)}$.
}

\begin{abstract}
ABSTRAK
Perpustakaan adalah suatu ruangan yang dikelola oleh lembaga pendidikan yang digunakan untuk sarana tempat belajar yang menyediakan berbagai macam koleksi buku. Sekolah merupakan bangunan atau lembaga untuk sarana dan prasarana belajar dan mengajar serta tempat bagi murid-murid untuk menerima dan memberi pelajaran. Untuk mewujudkan perpustakaan yang terorganisasi secara baik dan sistematis. Maka perpustakaan harus mempunyai aplikasi perpustakaan berbasis web, yang dapat memberikan kemudahan bagi proses peminjaman atau pencarian buku di perpustakaan sekolah tersebut. Aplikasi perpustakaan berbasis multitenant ini dibuat sebagai solusi untuk sekolah-sekolah yang tidak memiliki kecukupan finansial. Hasil dari penelitian ini adalah sebuah penyedia layanan yang dapat diakses dengan website. Layanan yang tersedia pada website dapat diakases secara penuh oleh pustakawan diantaranya mendaftar user baru, login user, menginputkan buku, menginputkan anggota, pendataan peminjaman dan pengembalian buku yang lebih terdata. Untuk tampilan admin diantaranya mendata pustakawan, menyutujui permintaan tambah jumlah buku pustakawan, dan menagih pembayaran tambah jumlah buku.
\end{abstract}

Kata Kunci : Sistem Informasi, Perpustakaan, Multitenant.

\section{PENDAHULUAN}

Perpustakaan merupakan sebuah ruangan yang dikelola oleh suatu lembaga pendidikan yang menyediakan berbagai macam koleksi buku. Sekolah merupakan bangunan atau lembaga untuk sarana dan prasarana belajar dan mengajar serta tempat bagi murid-murid untuk menerima dan memberi pelajaran. Untuk memelihara dan meningkatkan efisiensi dan efektifitas proses belajar-mengajar salah satunya menggunakan perpustakaan sebagai media pembelajaran, untuk mewujudkan per-pustakaan yang terorganisasi secara baik dan sistematis. Maka perpustakaan harus mem-punyai aplikasi perpustakaan berbasis web, yang dapat memberikan kemudahan bagi proses peminjaman atau pencarian buku di perpustakaan sekolah tersebut. Seperti yang diketahui tidak semua sekolah mempunyai aplikasi perpustakaan berbasis web, dikarenakan terbatasnya finansial, tenaga dan waktu. Menurut UU 43 tahun 2007 tentang Perpustakaan Pasal 14 Ayat 3 yang berbunyi "Setiap perpustakaan mengembangkan layanan perpustakaan sesuai dengan kemajuan teknologi informasi dan komunikasi".

Sistem informasi berbasis web, hanya ada di sekolah-sekolah tertentu. Oleh karena itu, diperlukan aplikasi perpustakaan berbasis Multitenant, sehingga sekolah-sekolah yang tidak memiliki kecukupan finansial dapat menggunakan aplikasi tersebut dengan cara menyewa. Tujuannya adalah untuk membangun suatu aplikasi yang dapat digunakan oleh sekolah-sekolah yang tidak cukup memiliki finansial, sehingga guru maupun murid tetap dapat menikmati fasilitas aplikasi perpustakaan seperti sekolah-sekolah lain. Dengan adanya aplikasi perpustakaan yang memanfaatkan internet sebagai media pelayanan maka dapat memudahkan petugas untuk memberikan pelayanan terhadap anggota secara optimal, dan anggota dapat mengakses informasi via internet dalam waktu 24 jam serta dapat diakses dimana saja.

\section{BAHAN DAN METODE}

a. Sistem Informasi Perpustakaan

Sistem informasi perpustakaan adalah sistem yang dibuat untuk memudahkan petugas perpustakaan dalam mengelola suatu perpustakaan. Semua di proses secara komputerisasi yaitu digunakannya suatu software tertentu seperti software pengolah database. Petugas perpustakaan dapat selalu memonitor tentang ketersediaan buku, daftar buku baru, peminjaman buku dan pengembalian buku (Saputro, 2009).

Sistem informasi perpustakaan merupakan kumpulan informasi yang saling terintegrasi dalam sebuah perpustakaan. Tujuannya untuk 
memudahkan para pengguna dalam mencari bahan pustaka dibutuhkan sebuah sistem informasi perpustakaan yang baik untuk kemudahan dalam pelayanan (Tanto, 2010).

\section{b. Web Application}

Aplikasi web merupakan sebuah aplikasi yang menggunakan teknologi browser untuk menjalankan aplikasi dan diakses melalui jaringan komputer (Remick, 2011). Sedangkan menurut Rouse (2011) aplikasi web adalah sebuah program yang disimpan di Server dan dikirim melalui internet dan diakses melalui antarmuka browser. Model web aplication dapat dilihat pada gambar 1 .

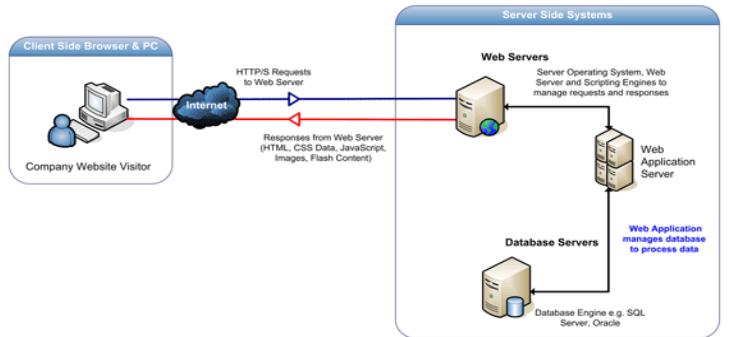

Gambar 1. Web Application Model

\section{c. PHP (PHP Hypertext Preprocessor)}

PHP adalah bahasa pemrograman script. Perbedaannya adalah, jika Java Script secara umum digunakan untuk pemrograman di sisi klien, PHP secara umum digunakan untuk pemrograman di sisi server. PHP juga banyak dipakai untuk membuat suatu web dinamis walau tidak tertutup kemungkinan digunakan untuk pemakaian lainnya.

\section{d. Database MySQL}

Database MySQL merupakan aplikasi yang bersifat daemon atau menetap dalam memori yang berjalan bersama dengan sistem operasi microsoft windows. Interface utama MySQL database server adalah command line atau berbasis DOS sehingga diperlukan pengetahuan khusus mengenai pengguna perintah atau command dalam command shell MySQL (Andi, 2011).

\section{e. Cloud Computing}

Cloud computing pada dasarnya adalah menggunakan Internet-based service untuk mensupport business process, Kata-kata "Cloud" sendiri merujuk kepada simbol awan yang di dunia TI digunakan untuk menggambarkan jaringan internet (internet cloud). Cloud computing adalah gabungan pemanfaatan teknologi komputer ('komputasi') dan pengembangan berbasis Internet ('awan') (Iqbal Nurhadi, 2011).

\section{f. SaaS (Software as a Service)}

SaaS ini merupakan layanan Cloud Computing yang paling dahulu populer. Software as a Service ini merupakan evolusi lebih lanjut dari konsep ASP (Application Service Provider). Sesuai namanya, SaaS memberikan kemudahan bagi pengguna untuk bisa memanfaatkan sumberdaya perangkat lunak dengan cara berlangganan.
Sehingga tidak perlu mengeluarkan investasi baik untuk in house development ataupun pembelian lisensi. Dengan cara berlangganan via web, pengguna dapat langsung menggunakan berbagai fitur yang disediakan oleh penyedia layanan. Hanya saja dengan konsep SaaS ini, pelanggan tidak memiliki kendali penuh atas aplikasi yang mereka sewa. Hanya fitur-fitur aplikasi yang telah disediakan oleh penyedia saja yang dapat disewa oleh pelanggan.

\section{g. Multitenant}

Multitenant merupakan suatu prinsip dari arsitektur perangkat lunak, dimana sebuah perangkat lunak yang berjalan di atas server melayani banyak pengguna / tenant. Dengan prinsip multitenant ini, sebuah perangkat lunak dirancang untuk memiliki partisi data yang berbeda dan dapat dikonfigurasi (Riayanato, 2013).

Pada Single Instance - Multitenant Architecture model, analoginya adalah satu buah slot apartement yang disewa oleh beberapa orang, dapat dilihat pada gambar 2. Sementara Single Tenant - Multiinstance Architecture model dianalogikan dengan kita menyewa satu buah slot apartement untuk diri sendiri, dapat dilihat pada gambar 3 .

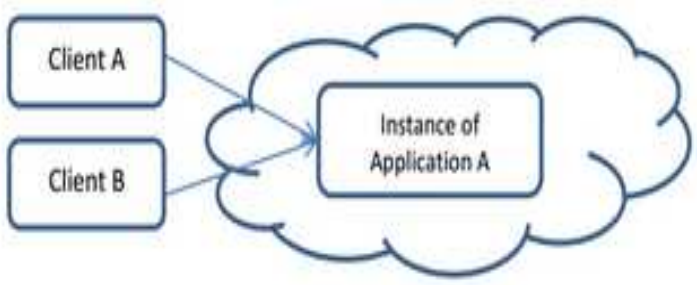

Gambar 2. Single Instance - Multitenant Architecture

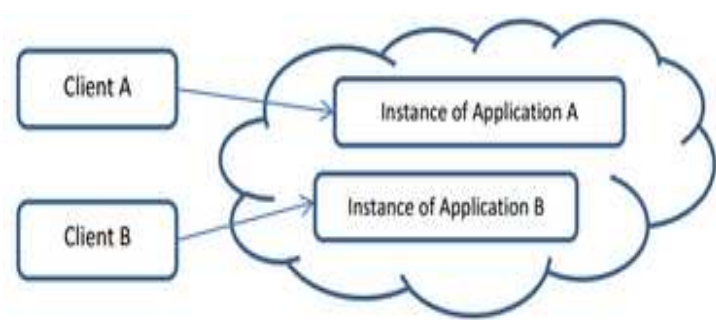

Gambar 3. Single Tenant - Multiinstance Architecture

\section{h. UML (Unified Modeling Languange)}

UML (Unified Modeling Languange) dirilis tahun 1987 sebagai sebuah metode untuk menggambarkan desain softwere. UML (Unified Modelling Language) sebagai notasi pemodelan standar industri untuk visualisasi sistem berorientasi obyek dan juga sebagai platform untuk mempercepat proses pengembangan aplikasi. UML menawarkan sebuah standar untuk merancang model sebuah sistem (Sholiq, 2006). 
Keuntungan menggunakan UML adalah :

1. Software terdesain dan terdokumentasi secara profesional sebelum dibuat, dan dapat diketahui secara persis apa yang nantinya didapatkan.

2. Oleh karena mendesain terlebih dahulu, reusable code dapat dikode dengan tingkat efesiensi tinggi.

3. Lubang dapat diketemukan pada saat menggambar desain.

4. Dengan UML, dapat dilihat gambaran besarnya.

\section{i. Metode Pengembangan Sistem}

Metode waterfall merupakan metode yang sering digunakan oleh penganalisa sistem pada umumnya. Inti dari metode waterfall adalah pengerjaan dari suatu sistem dilakukan secara berurutan atau secara linear.

\section{HASIL DAN PEMBAHASAN}

\section{a. Deskripsi Sistem}

Aplikasi sistem informasi ini di bangun menggunakan bahasa pemrograman PHP (PHP Hypertext Preprocessor) dan MySql yang berfungsi sebagai media penyimpanan data, yang terdiri dari beberapa tabel yang saling berhubungan. Tabel basis data yang saling terkait memiliki relasi yang menghubungkan data-data yang di butuhkan dan dapat di panggil melalui tabel yang lain.

Cloud merupakan admin sebagai penyedia layanan aplikasi infrastructure layer dan juga aplikasi yang akan digunakan oleh user layers. User layers yang ingin menggunakan layanan aplikasi harus melakukan registrasi terlebih dahulu di website. Setelah user layers registrasi, maka user layers mendapatkan hak akses untuk mengelola aplikasi tersebut. Sehingga seolah-olah aplikasi tersebut hanya digunakan oleh satu pengguna. Pengaturan hak akses user layers di atur oleh management system. Arsitektur sistem dapat dilihat pada gambar 4.

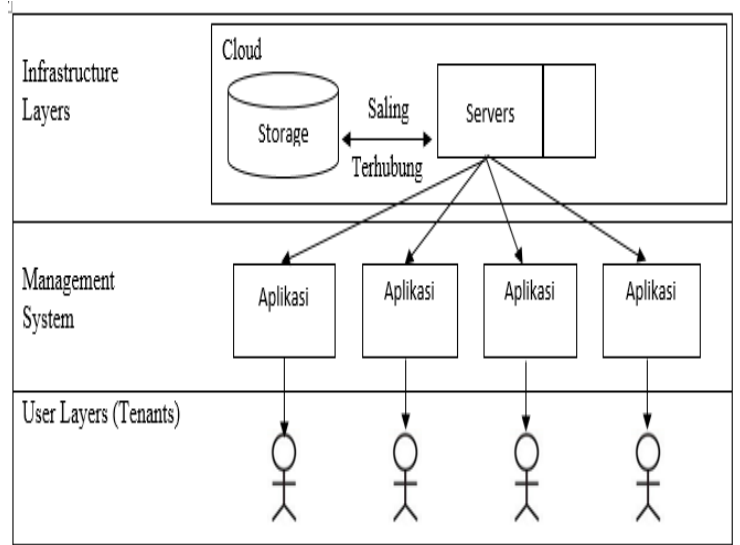

Gambar 4. Arsitektur Sistem

\section{b. Use Case Diagram Pengelolaan file}

Diagram use case menggambarkan aktifitas yang dilakukan oleh suatu sistem dari sudut pandang pengamatan luar, dapat ditunjukkan seperti pada gambar 5. Dalam sistem perancangan dan implementasi aplikasi perpustakaan sekolah berbasis multitenant terdapat 3 aktor yang terlibat, antara lain :

\section{Admin}

Admin adalah pengelola aplikasi yang memiliki hak akses terhadap pendataan pustakawan, menerima tambah jumlah buku, dan membuat tagihan.

2. Pustakawan

Pustakawan adalah aktor yang menggunakan aplikasi, dan memiliki hak akses terhadap aplikasi tersebut.

3. User

User adalah aktor yang menggunakan fitur aplikasi perpustakaan yaitu search buku.

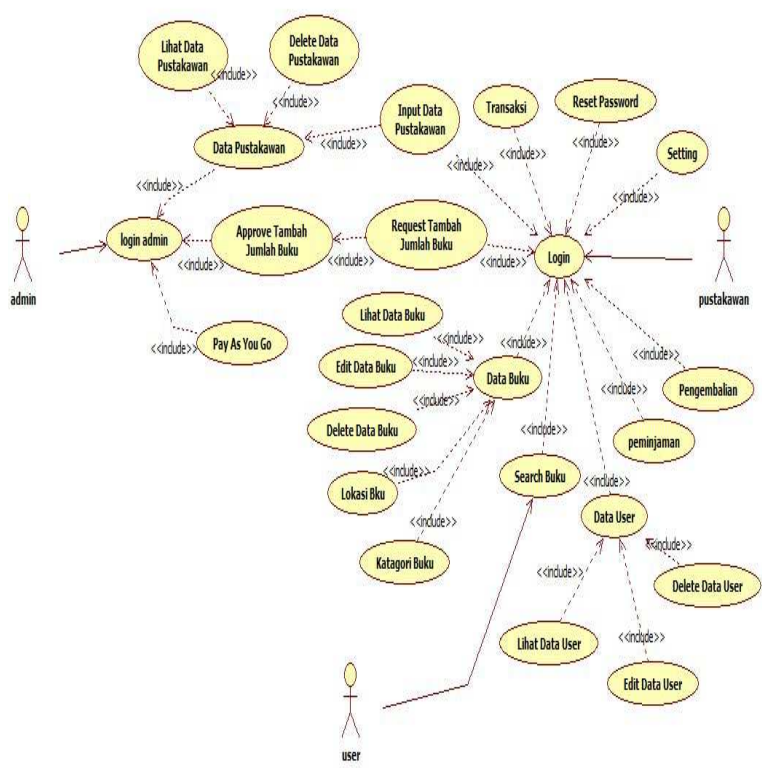

Gambar 5. Use case Diagram Pengelola File

\section{c. Activity Diagram}

1. Activity Diagram Pustakawan

Activity Diagram Registrasi Pustakawan dan Menginputkan Buku

Pustakawan yang ingin menginputkan data buku harus mendaftar terlebih dahulu, agar mendapatkan hak akses untuk masuk ke sistem. Setelah login berhasil maka pustakawan dapat menginputkan data buku yang ada di website. Seperti pada gambar 6 . 


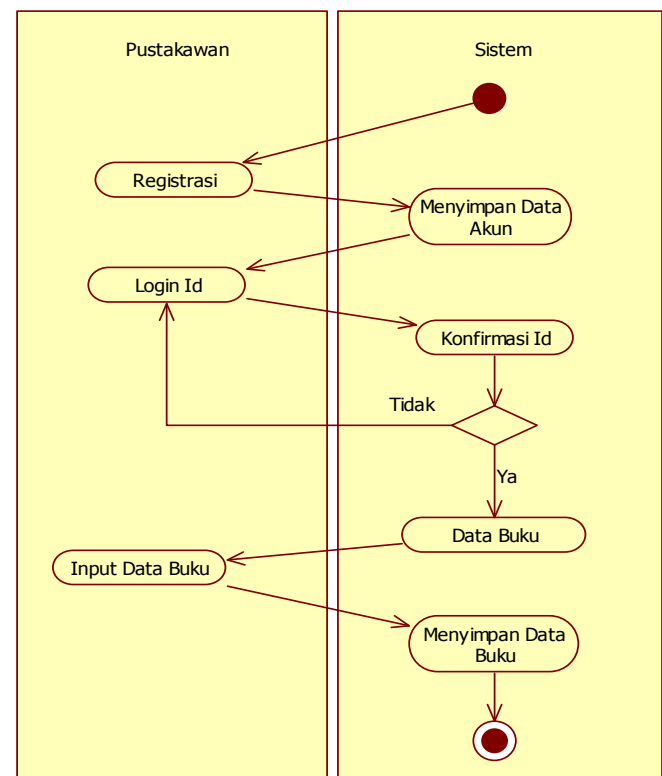

Gambar 6. Activity Diagram Pustakawan dan Menginputkan Buku

\section{Activity Diagram Peminjaman Buku}

Pada pengguna aplikasi terlihat aktifitas login dan sistem akan memproses login tersebut jika berhasil maka akan menampilkan data pinjaman, sehingga pengguna dapat menginputkan NIS dan ISBN buku lalu menyimpannya.seperti pada gambar 7.

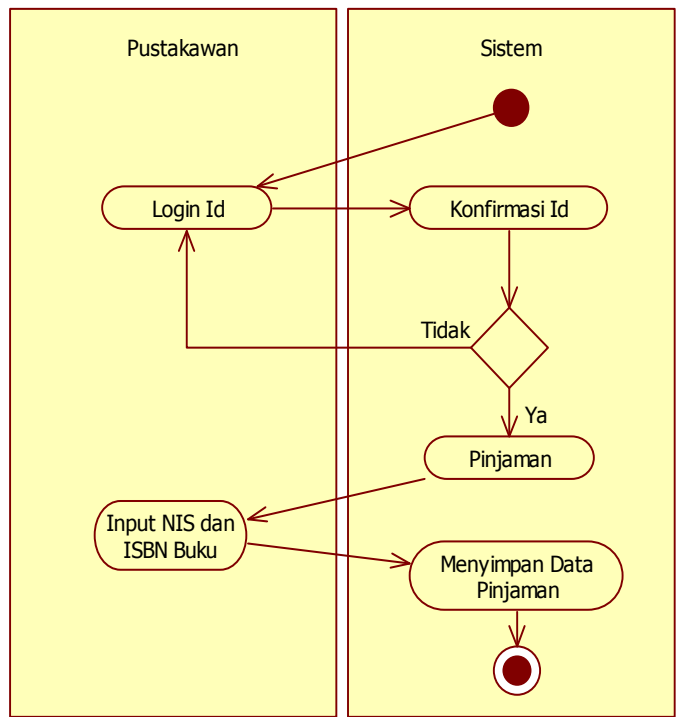

Gambar 7. Activity Diagram Peminjaman Buku

\section{Activity Diagram Pengembalian Buku}

Pada pengguna aplikasi terlihat aktifitas login dan sistem akan memproses login tersebut jika berhasil maka akan menampilkan data pengembalian, sehingga pengguna dapat menginputkan NIS lalu memprosesnya, maka akan muncul data pinjaman beserta dengan denda keterlambatan jika melewati waktu yang telah diberikan. Seperti pada gambar 8.

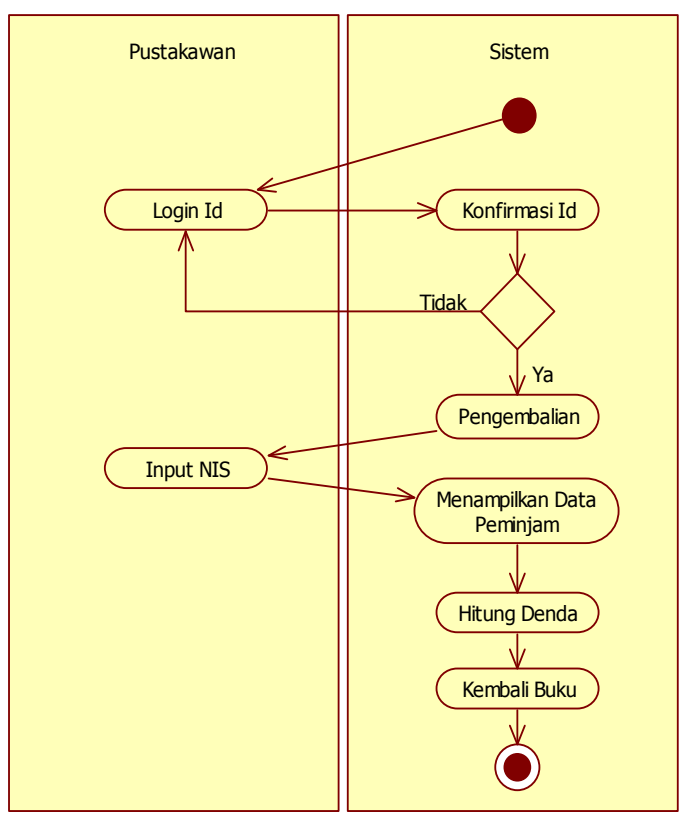

Gambar 8. Activity Diagram Pengembalian Buku

Activity Diagram Request \& Approve Jumlah Buku

Pada pengguna aplikasi terlihat aktifitas login dan sistem akan memproses login tersebut jika berhasil maka pustakawan dapat request tambah jumlah buku dengan cara menginputkan jumlah buku yang diinginkan, lalu sistem menyimpan data, dan menampilkan data agar admin dapat mengapproval request buku, jika disetujui maka sistem akan mengupdate jumlah buku pustakawan. Seperti pada gambar 9 .

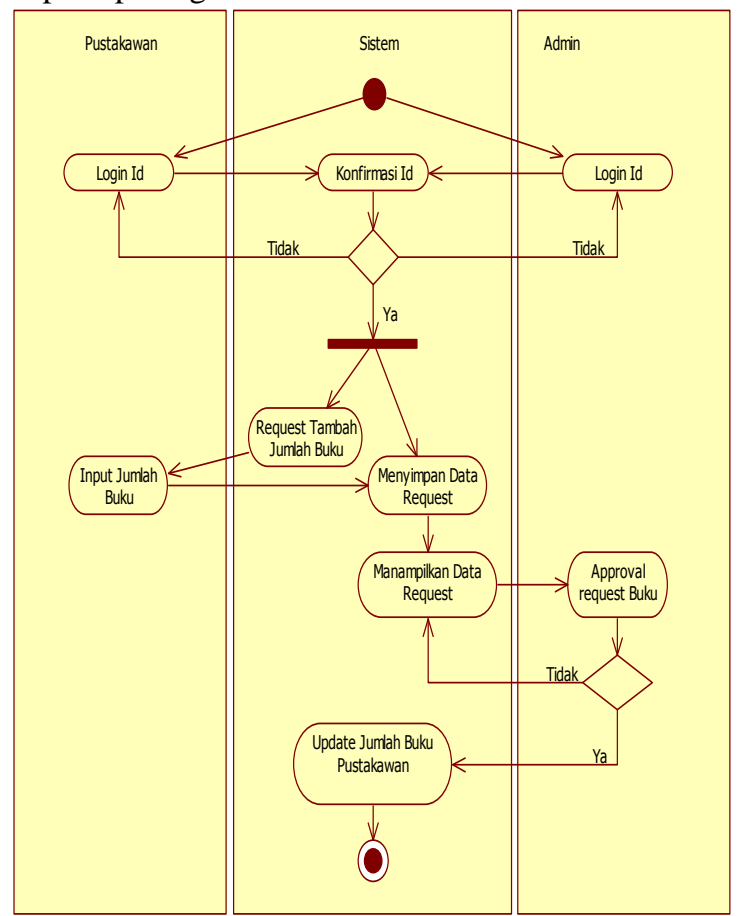

Gambar 9. Activity Diagram Request dan Approve Jumlah Buku 


\section{Activity Diagram Admin}

\section{Activity Diagram Admin lihat Data Pustakawan}

Pada pengguna aplikasi terlihat aktifitas admin melakukan login terlebih dahulu, lalu sistem akan memproses login tersebut jika berhasil maka sistem akan menampilkan data pustakawan/pengguna aplikasi. Seperti pada gambar 10 .

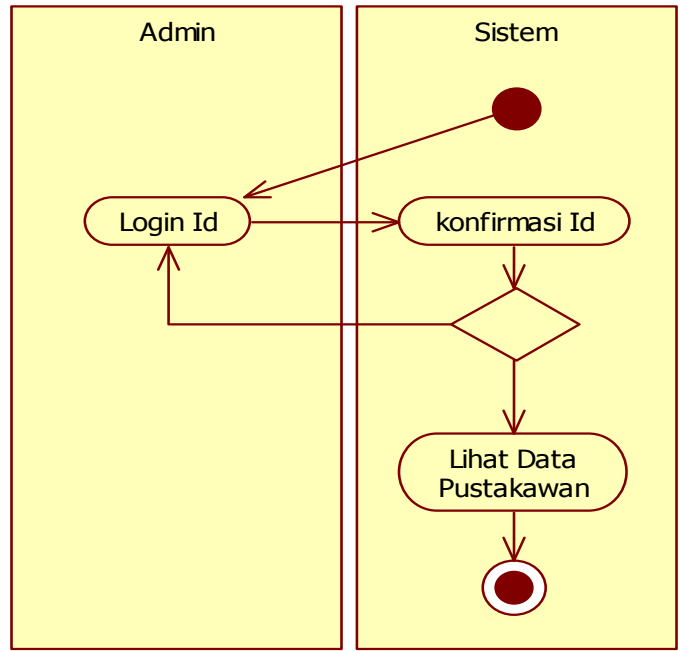

Gambar 10. Activity Diagram Admin lihat Data Pustakawan

\section{Activity Diagram Admin Approve Tambah Jumlah Buku}

Pada pengguna aplikasi terlihat aktifitas admin melakukan login, lalu sistem akan memproses login tersebut jika berhasil maka sistem akan menampilkan data request tambah jumlah buku. Seperti pada gambar 11 .

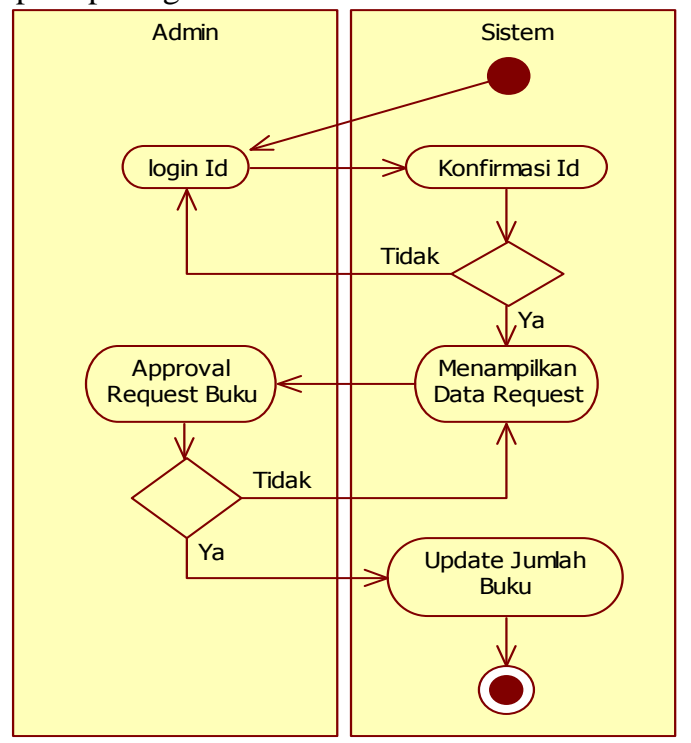

Gambar 11. Activity Diagram Admin Approve Tambah Jumlah Buku

\section{Activity Diagram Pay As You Go Admin}

Pada pengguna aplikasi terlihat aktifitas admin melakukan login, lalu sistem akan memproses login tersebut jika berhasil maka sistem akan menampilkan data tagihan, lalu admin membuat tagihan yang ditujukan untuk pengguna aplikasi yang melakukan request tambah jumlah buku. Seperti pada gambar 12 .

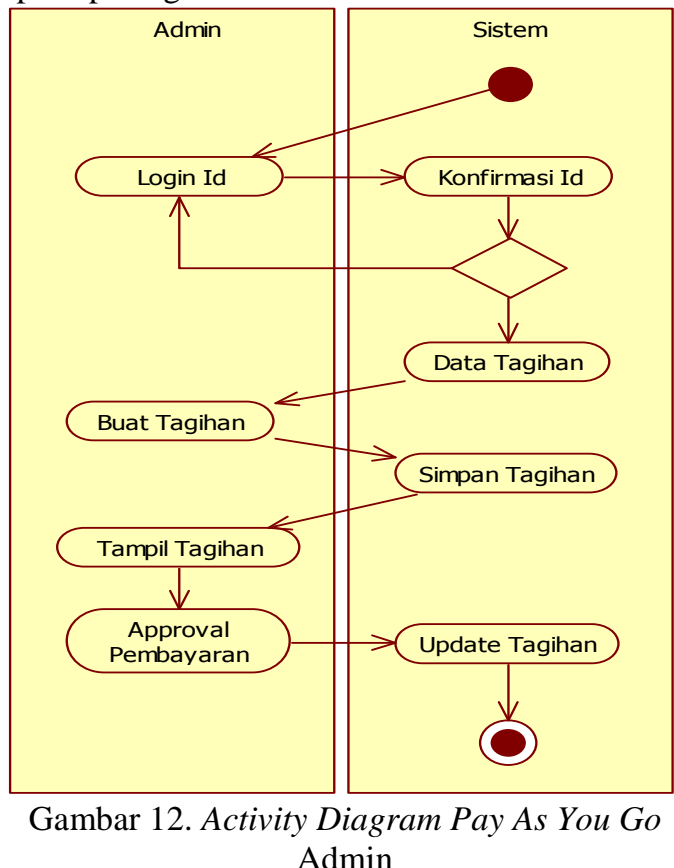

\section{d. Class Diagram Pengelolaan File}

Pada sistem pengelolaan aplikasi perpustakaan berbasis multitenant ini terdapat 13 buah class, dimana seluruh class saling terkait diantaranya adalah class tb_pustakawan, class tb_buku, class tb_user, class tb_lokasibuku, class kategoribuku, class tb_pinjaman, class tb_pengembalian, class tb_request, class tb_stokbuku, class tb_bukutamu, class tb_payasyougo, class tb_jenkel dan class tb_setting. Seperti pada gambar 13.

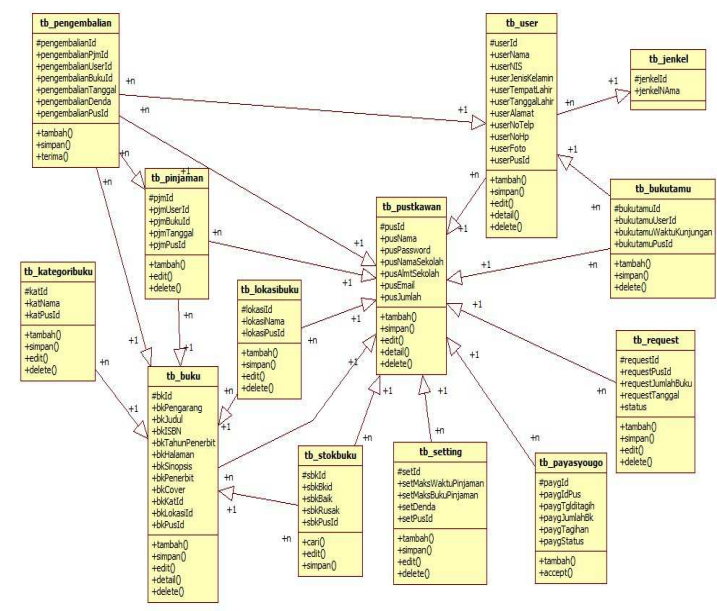

Gambar 13. Class Diagram Pengelolaan File

\section{IMPLEMENTASI SISTEM}

Tahap implementasi pengembangan perangkat lunak merupakan proses pengubahan spesifikasi sistem menjadi sistem yang dapat dijalankan. Tahap ini merupakan lanjutan dari proses pe-rancangan, yaitu proses pemrograman perangkat lunak sesuai dengan spesifikasi dan desain sistem. 


\section{a. Tampilan website}

\section{Layanan website}

Merupakan halaman utama yang muncul ketika masuk website pertama kali. Menu yang terdapat pada layanan website meliputi Login, Daftar Akun, dan Cari Buku. Seperti pada gambar 14.

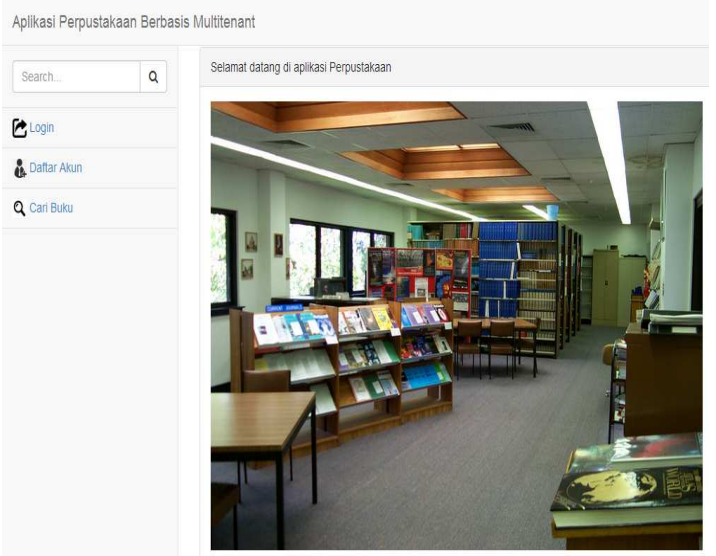

Gambar 14. Tampilan Website

\section{Cari Buku}

Terdapat halaman menu cari buku yang digunakan oleh user untuk mencari buku dengan mengisi nama pengarang, penerbit, judul buku atau sinopsis. Seperti pada gambar 15 .

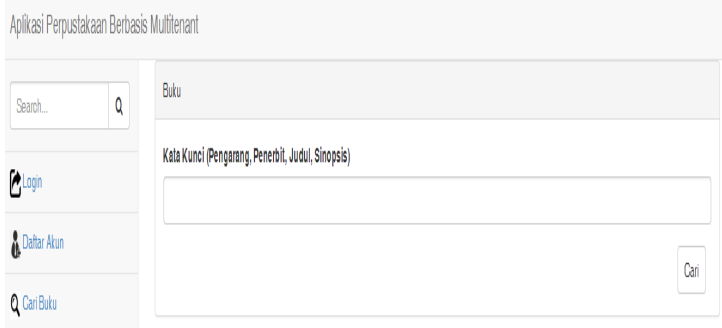

Gambar 15. Tampilan Menu Cari Buku

\section{b. Tampilan Antarmuka Pustakawan} Halaman Menu Dashboard

Halaman menu dashboard ini merupakan tampilan utama pustakawan setelah melakukan login. Seperti pada gambar 16.

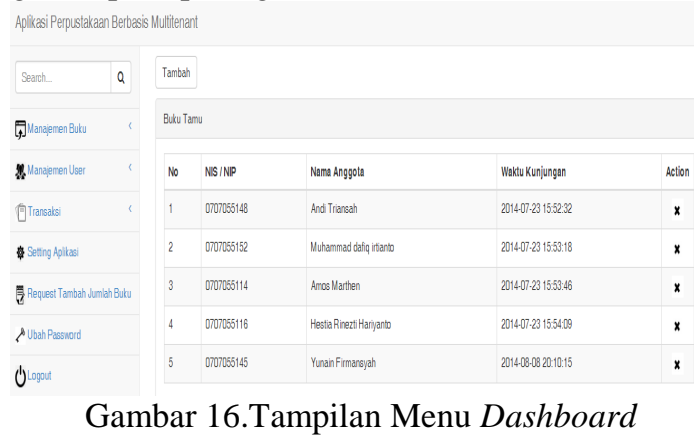

\section{Halaman Menu Buku}

Halaman menu buku digunakan oleh pustakawan untuk menampilkan data buku yang sudah diinputkan. Seperti pada gambar 17.

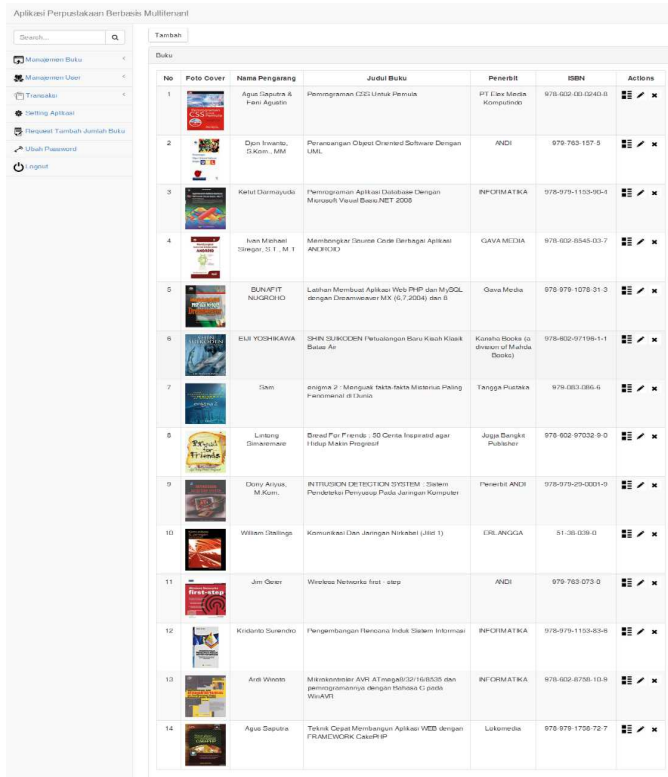

Gambar 17. Tampilan Menu Buku

\section{Halaman Menu User}

Halaman menu user digunakan untuk menampilkan data-data user yang telah diinputkan oleh pustakawan. Seperti pada gambar 18 .

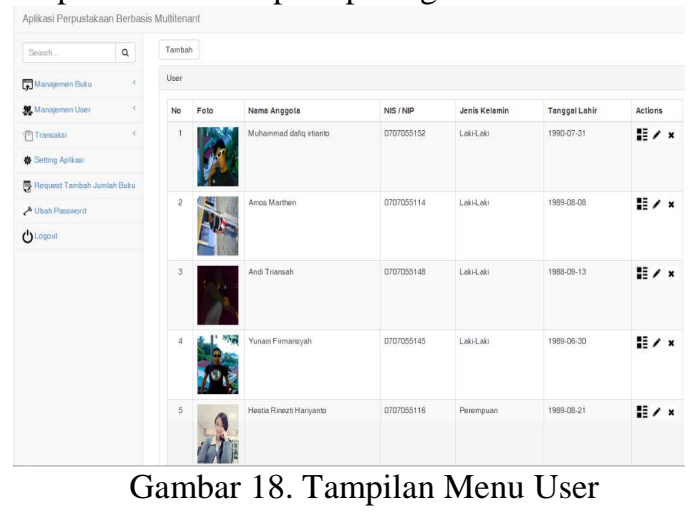

\section{Halaman Menu setting Aplikasi}

Halaman menu setting aplikasi ini digunakan oleh pustakawan untuk menampilkan batas waktu pinjaman, batas peminjaman buku dan denda keterlambatan. Seperti pada gambar 19.

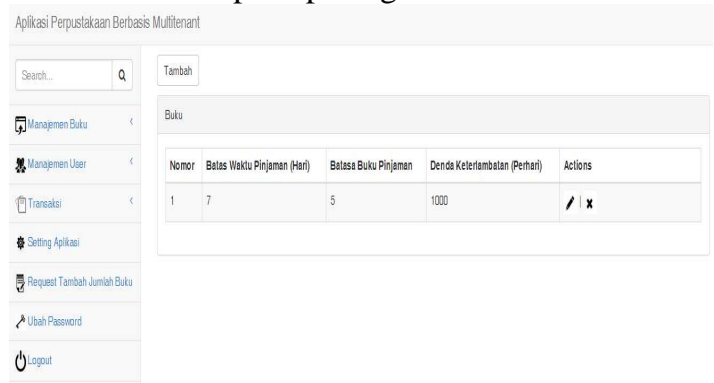

Gambar 19. Tampilan Menu User

\section{Halaman Menu Peminjaman}

Halaman menu peminjaman digunakan oleh pustakawan untuk menampilkan data anggota yang meminjam buku. Seperti pada gambar 20 . 


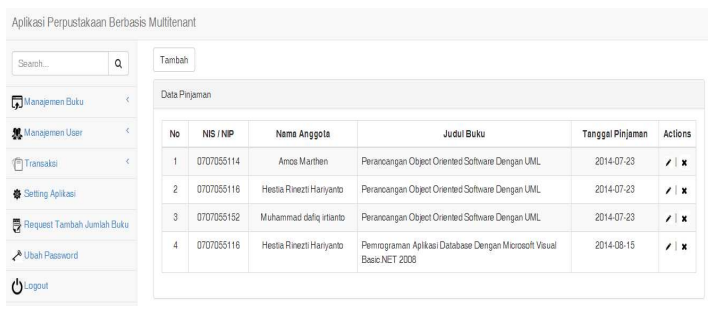

Gambar 20. Tampilan Menu Peminjaman

\section{Halaman Menu Pengembalian}

Halaman menu pengembalian digunakan untuk melihat data anggota yang mengembalikan buku, serta melihat jikalau ada denda keterlambatan. Seperti pada gambar 21.

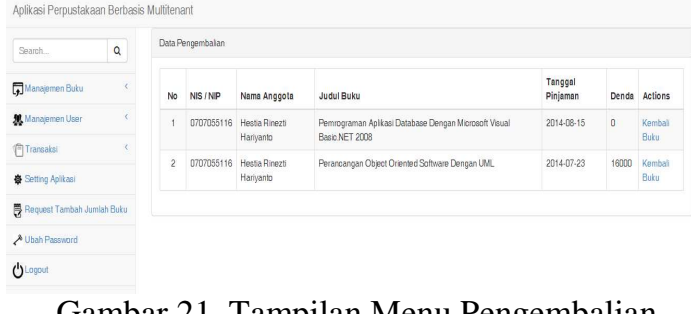

Halaman Menu Request Tambah Jumlah Buku

Halaman menu request tambah jumlah buku digunakan untuk menampilkan data pengguna aplikasi / pustakawan yang telah menginputkan berapa jumlah buku yang diinginkan. Seperti pada gambar 22.

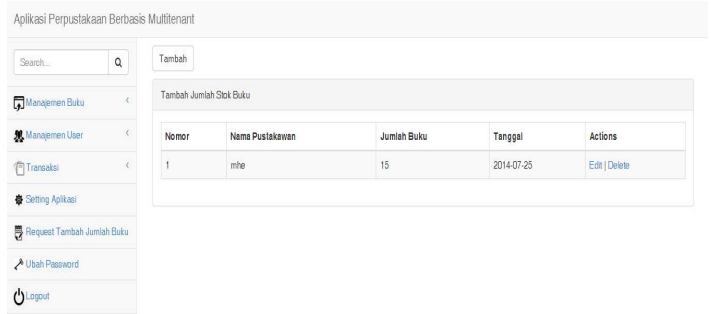

Gambar 22.Tampilan Menu Request Tambah Jumlah Buku

\section{c. Layanan Antarmuka Admin}

\section{Halaman Dashboard dan Menu Pustakawan}

Halaman dashboard merupakan halaman yang akan muncul pertama kali ketika admin melakukan login. Ketika admin melakukan login maka langsung menampilkan data pengguna aplikasi / pustakawan yang menggunakan aplikasi ini. Seperti pada gambar 23 .

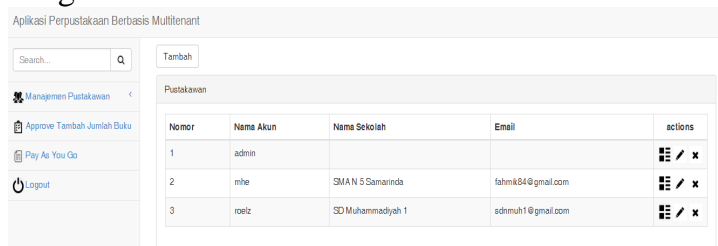

Gambar 23. Dashboard dan Menu Pustakawan

Halaman Menu Approve Tambah jumlah Buku

Halaman menu approve tambah jumlah buku digunakan untuk menampilkan data dari pengguna aplikasi/pustakawan yang telah melakukan request tambah jumlah buku. Terdapat dua tombol di dalam menu ini yaitu accept untuk menerima dan denied untuk menolak. Seperti pada gambar 24.

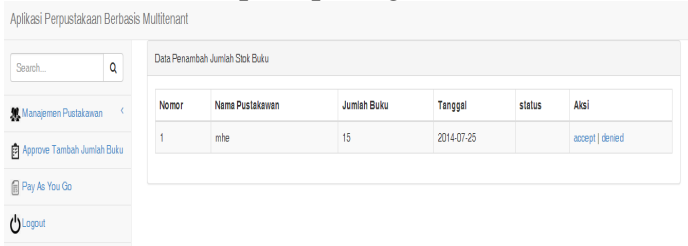

Gambar 24. Tampilan Menu Approve Tambah Jumlah Buku

\section{Halaman Menu Pay As You Go}

Halaman menu pay as you go digunakan untuk menagih pembayaran kepada pustakawan yang menggunakan menu request tambah jumlah buku dengan membayar jumlah buku yang telah digunakan. Seperti pada gambar 25.

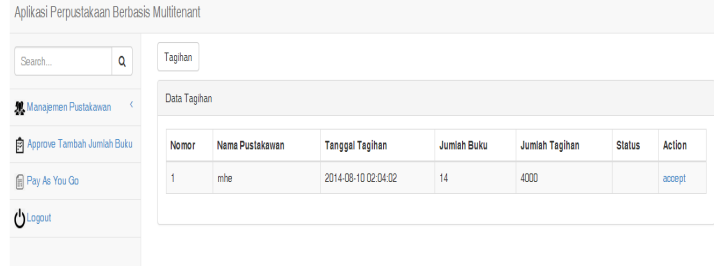

Gambar 25. Tampilan Menu Pay As You Go

\section{KESIMPULAN}

Berdasarkan hasil pengujian sistem yang dilakukan, dapat diambil kesimpulan beberapa hal antara lain :

1. Telah dibangun aplikasi perpustakaan yang dapat digunakan sebagai alat bantu media pembelajaran. Untuk mewujudkan perpustakaan yang terorganisasi secara baik dan sistematis. Maka perpustakaan harus mempunyai aplikasi perpustakaan berbasis web, yang dapat memberikan kemudahan bagi proses peminjaman atau pencarian buku di perpustakaan sekolah tersebut.

2. Dengan adanya aplikasi perpustakaan ini kualitas pelayanan terhadap anggota perpustakaan dapat lebih meningkat dan dapat membantu dalam efisiensi waktu.

3. Aplikasi perpustakaan ini dapat membantu anggota dalam mencari data buku yang dikehendaki.

4. Aplikasi perpustakaan ini juga dapat memberikan kemudahan bagi sekolah-sekolah yang tidak memiliki kecukupan finansial.

\section{DAFTAR PUSTAKA}

[1] Andi., 2011. Microsoft Visual Basic 2010 \& MySQL. Andi, Yogyakarta.

[2] Iqbal, N., 2011. Defenisi Cloud Computing. http:// www.iqbalnurhadi .com/2011 / 03/ definisi-cloud-computing/, (diakses tanggal 03 April 2014). 
[3] Library IT Telkom., 2008, Alat bantu Pemodelan Sistem. http://www.stt telkom.ac.id/index.php, (diakses tanggal 28 Maret 2014).

[4] Marlinda, L., 2004. Sistem Basis Data. Andi, Yogyakarta.

[5] Naiburg, E. and Maksimchuk, R., 2001, UML for Database design, USA ADDISON-WESLEY

[6] Ondyx., 2014. Defenisi Software as a Service. http://ondyx.blogspot.com /2014/02/pengertian-dan-definisi-cloudcomputing.html, (diakses tanggal 03 April 2014).

[7] Ozan., 2012. Pengertian Aplikasi Web. http://melengo.wordpress.com/2012/10/27/ aplikasi- web-itu-apa-sih/, (diakses tanggal 03 April 2014).

[8] Qalyubi Syihabuddin dkk., 2007, DasarDasar Ilmu Perpustakaan dan Informasi, U IN Sunan Kalijaga, Yogyakarta.
[9] Saputro., 2009. Sistem Informasi Perpustakaan. http://putroweb. blogspot.com /2009/03/sistem-informasi -perpustakaan .html, (diakses tanggal 26 Maret 2014).

[10] Sholiq., 2006. Pemodelan Sistem Informasi Berorientasi Objek dengan UML. Graha Ilmu, Yogyakarta.

[11] Sidik, B., 2006. Pemrograman WEB dengan PHP. Bandung: Informatika

[12] Syafi'i, M., 2004. Membangun Aplikasi Berbasis PHP dan MySQL. Andi, Yogyakarta.

[13] Tanto., 2010. Sistem Informasi Perpustakaan. http://reigant.Blogspot.com/2010/09/sisteminformasi-perpustakaan.html, (diakses tanggal 26 Maret 2014). 